\title{
れーしいまにあ・どのばに一ノ生體 染色二關入儿研究
}

第 1 編 序言並二生體染色陽性色素ノ檢索

京都帝國大學醫學部微生物學敉室（主任 木村廉敎授）

㗨學士南保吉 郎

Kichiro Nambo

（昭和16年 5 月 19 日受付）

\section{【内容 抄 錄】}

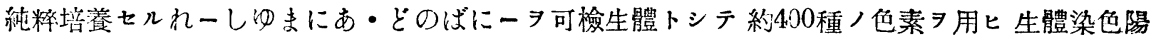
性色䋆/檢索 7 試 ミ染色陽性色素/若干 7 得, 且之等色素/理學的性狀, 各種可檢體 =於ヶル成 綪卜ノ比较, 色素ノ親和力, 生體=及ボス影響及ビ色素加培養基上ノ生體發育等=關シ研究七 リ.

目次

序 䓂

第 管 實驗方法

1 節 供試材

第 1 項 可檢生體

第 2 項 供試色素
第 2 節 赛驗操作及檢索方法

第 2 章 實驗戍績

第 3 章 總括前=考按

結 論

\section{序言}

生體染色 研究二關シテ八咸 $=P$. Ehrlich, Fischel, Meyer, Prowazek, Heidenhain 等, 諸學者 $=ヨ リ$ 基本的貫驗)行ハレタル事八成書, 示ス所ナルモ䧓知ノ如ク本學清野博士並=

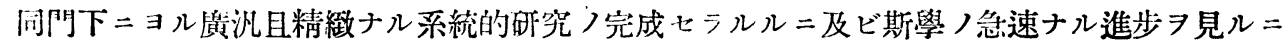

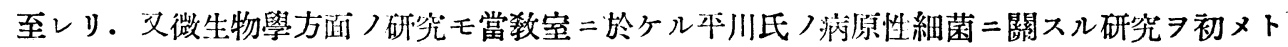

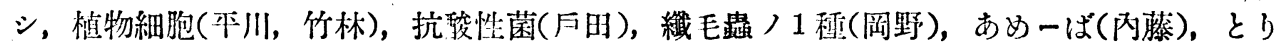

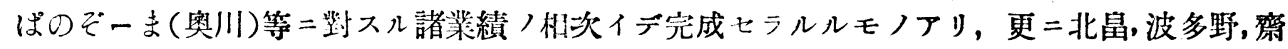

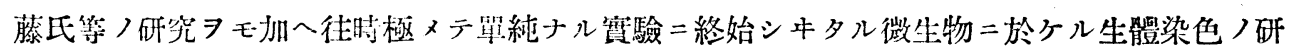
笁ェ漸ク多彩ナル面目习借フルニ至レリ。(松下, Prowazek, Giemsa, Vonuiller, Nirenstein)

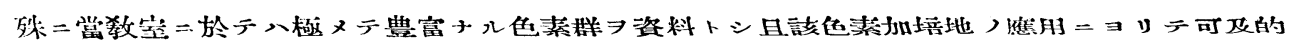


自然二近手環境二於テ逐次進展スル生體染色ノ研究二郎應シ之等色素ノ理學的諸性狀 7 究メ, 可檢噮二對スル親和力, 生體ノ形態, 㞄動並二發育二及ボス影響二就キテ累次貴重ナル知見 ヨ加ヘラレタルモノンシテ就中內藤氏つあめーばニ關スル形究二拂ハレタル努力八誠二容易

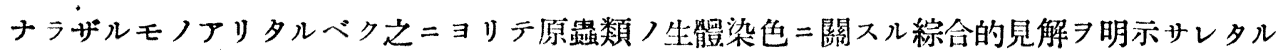
モノト言フヨ得ベシ. 余モ亦新可檢腰!:シテれーしゆまにあ・どのばに一ノ1株习入手シテ

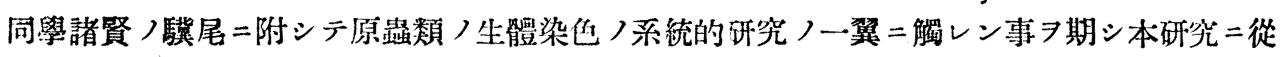
ヒタリ・而シテ該れーしゆ专にあ八今次支那事變二從ヒテ發病七ル患者ヨリ分離七ラレ當数 室二保存七ラルル1株ナリ。サレバ余八カカル病原性原蛅习以テ本實驗习隻ムル事ノ有意義 ナルョ思ヒ幸ニシテ何等カノ知見ヨ得テ更二臨休醫學ノ方面二迄發展寄與スル所アラバ喜ビ 之二過ルモノナシト信ズ. 茲二本䒈驗 ヨ開始スル二際シ從來ノ諸業績二對!!沼シ之ガ比較類推 ヨ試ムベク可及的其等ノ研究樣式二從ヒテ主要實驗材料ナル色素=關シ共通ナルモノヨ使用 セントシタルモ從來本學病理學教室二在リテ䐝驗ニ供サレシ色素群ハ既二一新七ラ: 余ノ入 手七ル色素群卜比較スル＝色素名，製造會社名二於テ殆ンド共通セズ從ツテ余ノ研究成績卜 教室ニ於ヶル從來つ成績トヨ比較檢討スルモ色素ノ微妙ナル個性二鑑ミ聊カ正缶 7 得ザル，

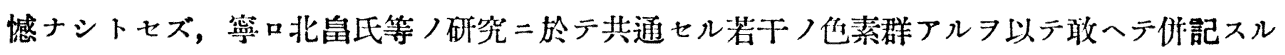
事ト七リ．以下供試色素 410 重二就イテ第 1 編生體染色陽性色素/系統的檢索, 第 2 編生體染 色陽性色素群 理學的性版, 色素ノ親和力, 各程可檢體=於ヶル成績卜ノ比較, 笨 3 編色素 ノ生體=及ボス影響就中色素加培地二於ヶル生體ノ發育狀况等ノ3 編=分チテ報告シ大方ノ 叱正 $\ni$ 仰ガントス.

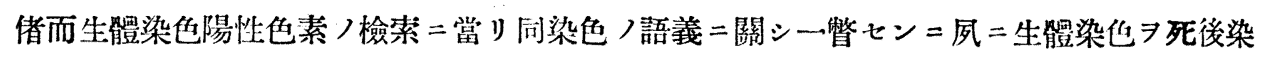

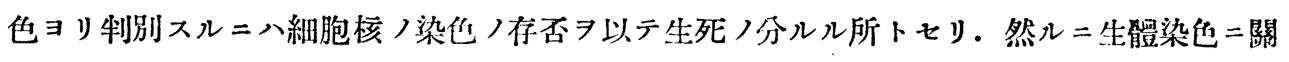
スル系統的研究ノ發展卜共二生體ノ染出像二對スル解釋モ移り, ソノ生命保持ノ程度 $=ヨ$, 或ハソノ實驗操作上二於ヶル相違ニヨリテ生體染色, 超生體染色, 死後染色 3 種二大别七 ラルルニ至レリ・之二關シテハ柇山呚授八夙沉ナル超生體染色ノ研究二於テ核モ亦生體並二 超生體染色七ラルルモノナル事ヨ確認七ラルル所アリ．核ノ染色八必シモ判別ノ基準夕リ得

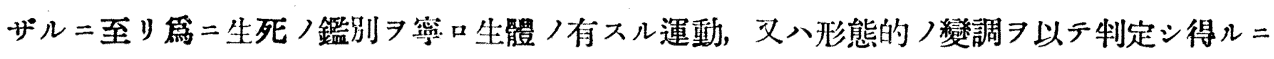
若カズト說ヘラルルニ至リタリ。文一般二生活機能ノ觀察容易ナラザル組織細胞ノ檢索二於

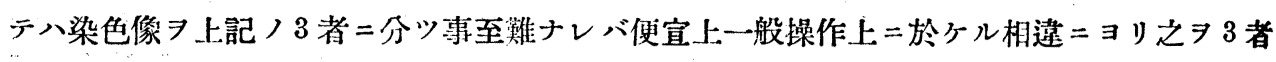
ニ分ツモうンシテ生䯣染色卜超生體染色卜ハ本質的ニハ同一ノモノナルベク，之二死後染色 ヨ加へタル 3 者八互二連續七ル一線上ニアルモノトセラレ, 岡野氏モ亦核染色二於テ八生體 染色並二死後染色八連續的ノモノナリト解スルニ至レリ。斯ノ如》染色像ノ制定甚ダ困難ナ 


南 保 告 郎 造

ル二鑑ミ當效䇪ニ於ケルあめーば並ニとりぱのぞーまノ生體染色ノ判定ニ八專ラ可檢鲴ノ有

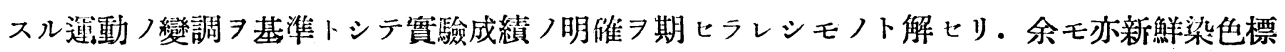

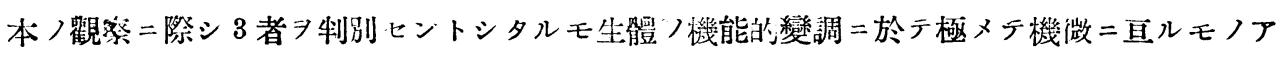

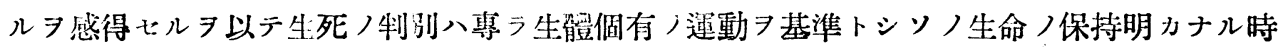
二染色像ノ發現スルモノ 從ヒタリ. 以下貫驗方法亚二檢索战績 7 記述ス.

\section{第 I章 實 驗方法}

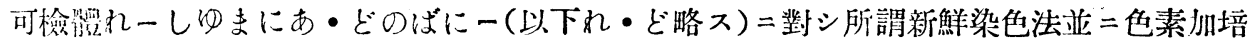

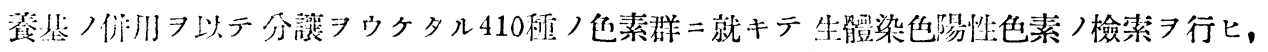

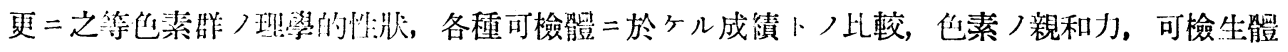

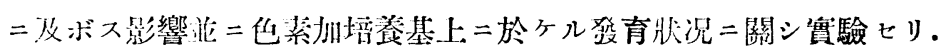

\section{第 । 節 供 試 材 料}

\section{第 1 項 供試可檢生體二就キテ}

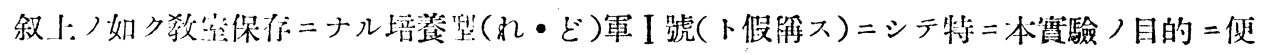

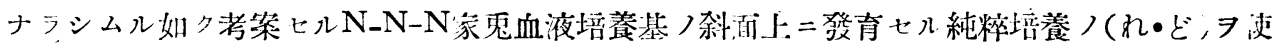

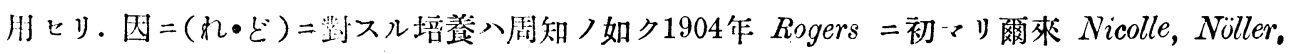
Wenyon 等ニヨリ種々ナル培養基考案ヒラレ近時孟，四㭡兩氏ノ塥地ヨモ玔へ各りノ研究ノ 目的二從ヒ活师七ラレタルモ勍モ培地ノ液狀相二發育七ル生體ニノミ留意シタルモノノ如ク

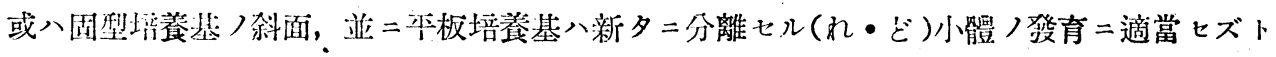
指摘ヒリ. 更 $=$ Nöller 八液狀相 $=$ 發育七ル(れ・ど)モN-N-N馬血夜葡萄糖加培食基ノ本

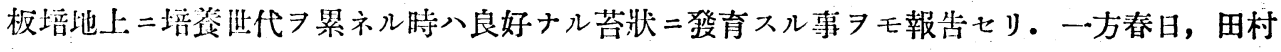

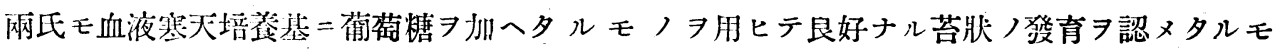

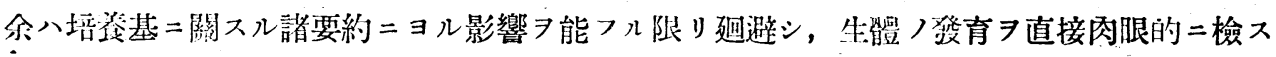
几事ノ䉮便ニシテ此較的正確ナル點, 培飬基製作上ノ便宜ヨモ考虑シテ所謂 N-N-N 家鬼血 液培基基 7 基本トシ, 家鬼血液 7 脫㵶維素シ ル後血液20cc 每 $=V i \operatorname{tamin} \mathrm{B}_{1}$ /結晶 7 注射 液习利シテ $0.25 \mathrm{mg} /$ 制二加へタルモノ ノ旮分ナル师现

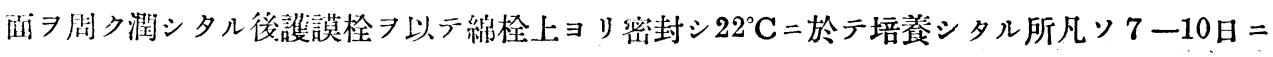

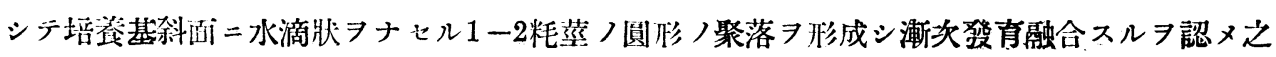




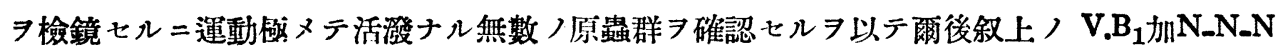
家秉血液培養基

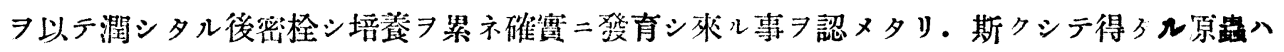

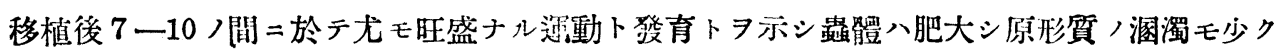
余ノ實驗ノ目的 $=$ 好適ナル

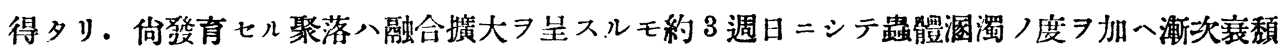

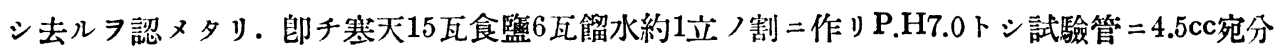
注滅菌七ル後用 $=$ 臨 $ミ 500^{\circ} \mathrm{C}$ 羭後 ノ上二培餋スルコト叙上ノ如丰運動發育共二旺盛ナル原蟲 7 使月 $=$ 供七リ.

\section{第 2 項 供 試 色 素}

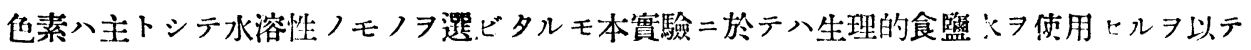
ソノ溶解二困難ナルモノアリ之等八凡テ㞦溫振璗シ可及的二本等ナル溶液タラシムル।共二 沈澱著シキモノ八之ヨ滤過シタル後用二供シタリ. 色素八靾モ加溫或八振蕰ニョリ脫色义八 異常ナル變色等习呈セズ, 即チ生理的食盃水 二新鮮染色法二用七, 又色素加培養基入夫 $1 \% 0,0.2 \% ， 0.1 \% 0$ ニルガ如ク二加へタル後15分 間宛3日間滅菌シ.ルモノ =上述ノ血液 7 加へ無菌ナル事 $コ$ 確メタル後使用セリ.

\section{第 2 節 實驗操作並=檢索方法}

1）新鮮染色法 可檢生體八培飬7一10日目ノ發育旺盛ナルモノノ1白金耳フ像メ载物硝子 上ニ取リタル1滴ノ所定色素液二手早ク混和シタル後被覆硝子ヨ以テ輕ク壓迫ヨ加へテ被上 直チ $=$ 檢鏡シ生體染色ノ有無 9 觀察シ同時=色素二依儿諸變異 7 檢シタリ. 染色像ノ制定八 既述ノ如ク生體個有ノ運動 色素ニョリ運動緩慢トナレルモノニ初マリ形態)變異スルモノ, 更二若干ノ色素二於テハ溶

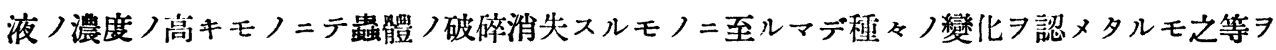
一括シ生體變異トシソノ程度二從七記號ヨ以テ記入七リ．檢索二要スル時閌八生體染色陽性 ナル場合八概亦數分ヨ越ヘズシテ確登シ得タルモ, 陰性色素=於テハ便苗上10-15分間ヨ以

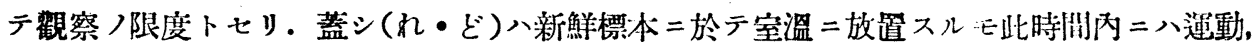
形態ニ著シキ變異习認ムルニ至ラザルモノナレバナリ。

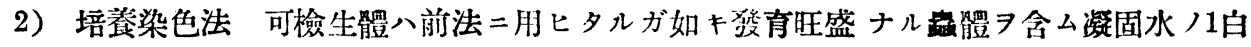
金耳量(約 $2 \mathrm{~mm}$ 蒙)ヨ色素加培食基 =塗抹ノ後密栓シ $22^{\circ} \mathrm{C}=$ テ 10 日間培飨シタル後ソノ斜面上 ノ聚落ョリ1白金耳量(約 $1 \mathrm{~mm}$ 蒙) ノ原蟲 ヨ取り載物硝子上ノ食監水ノ1滴卜手卢ク混和シ檢鏡 


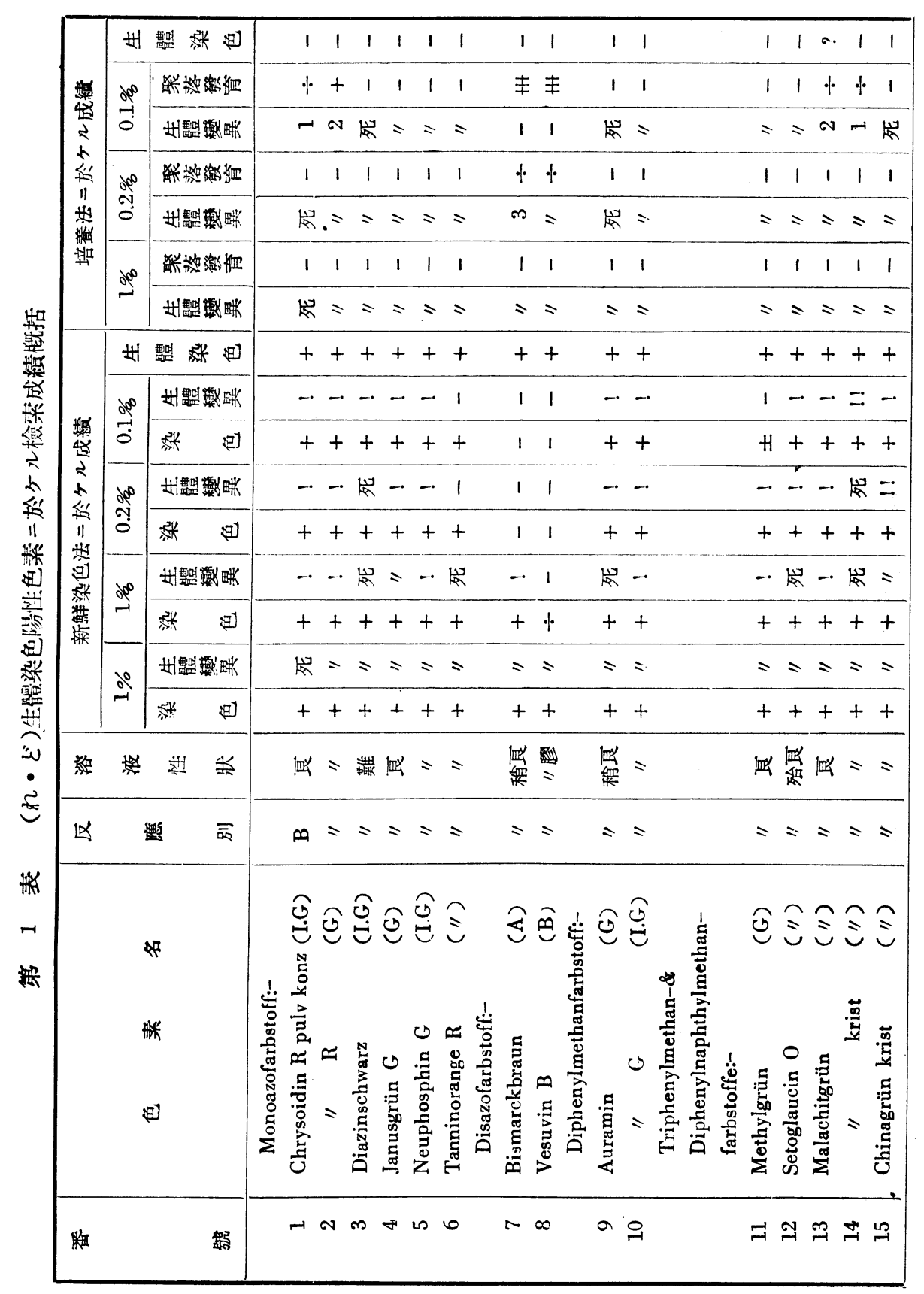




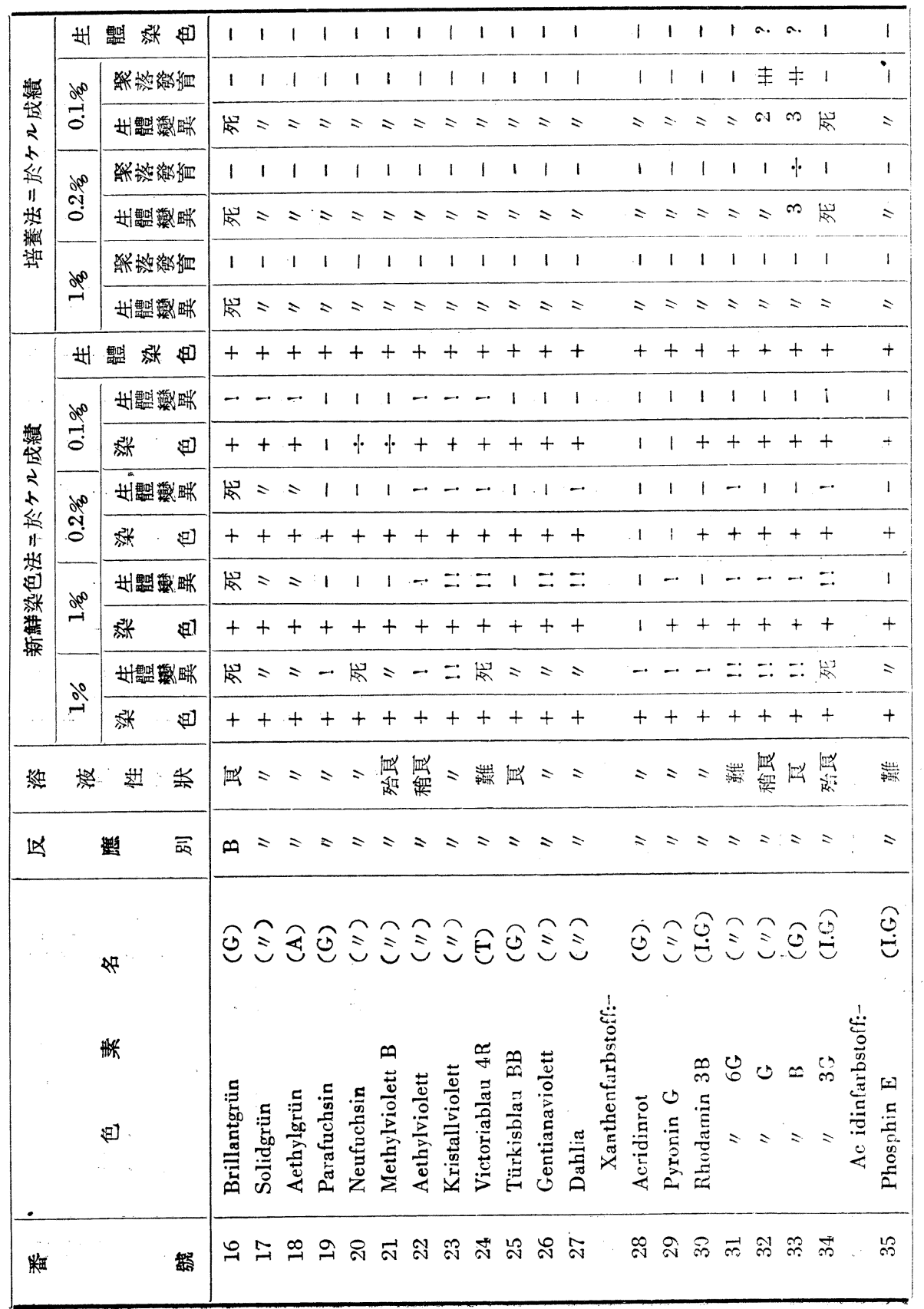


南保吉郎述

(1241)

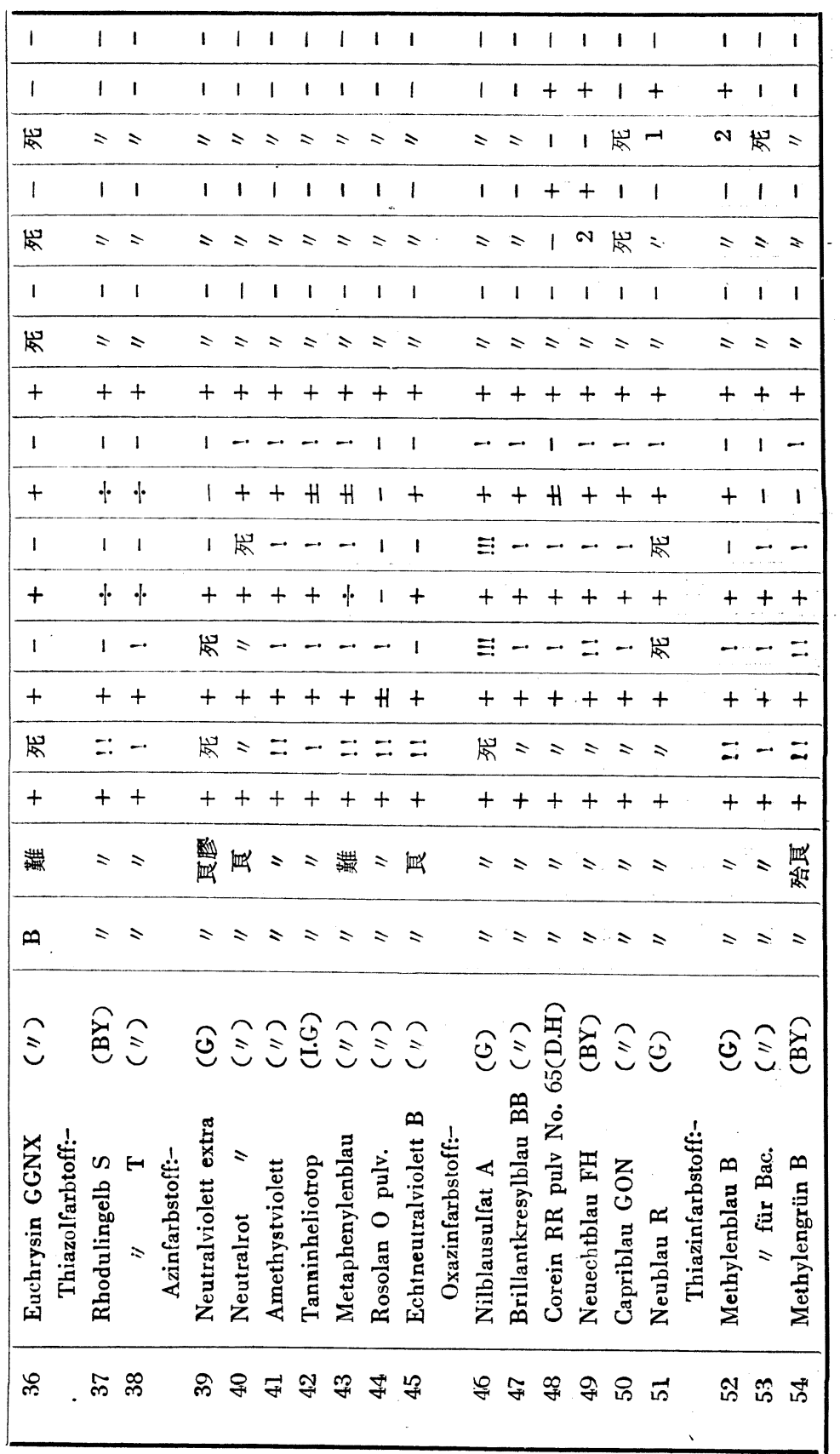




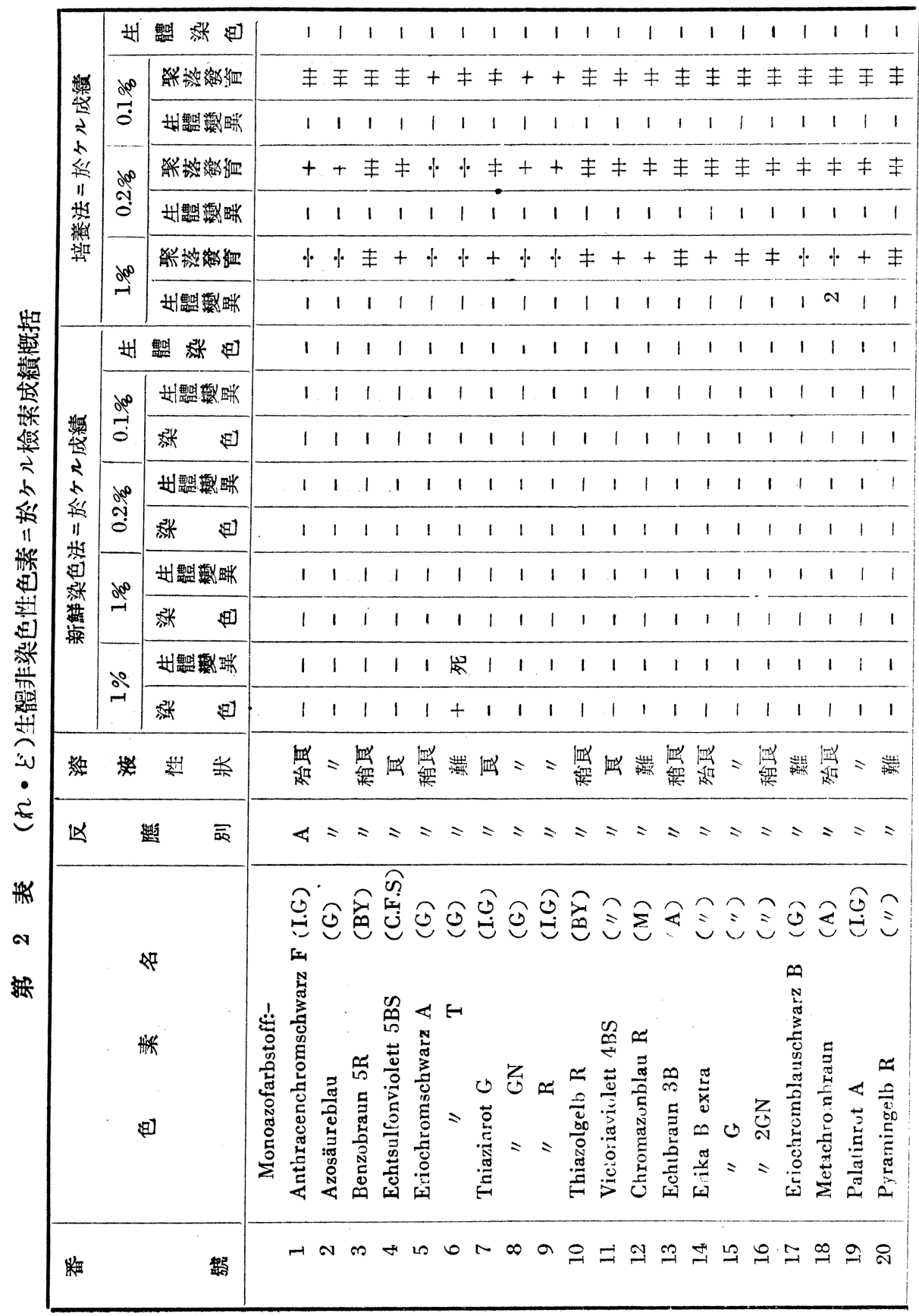




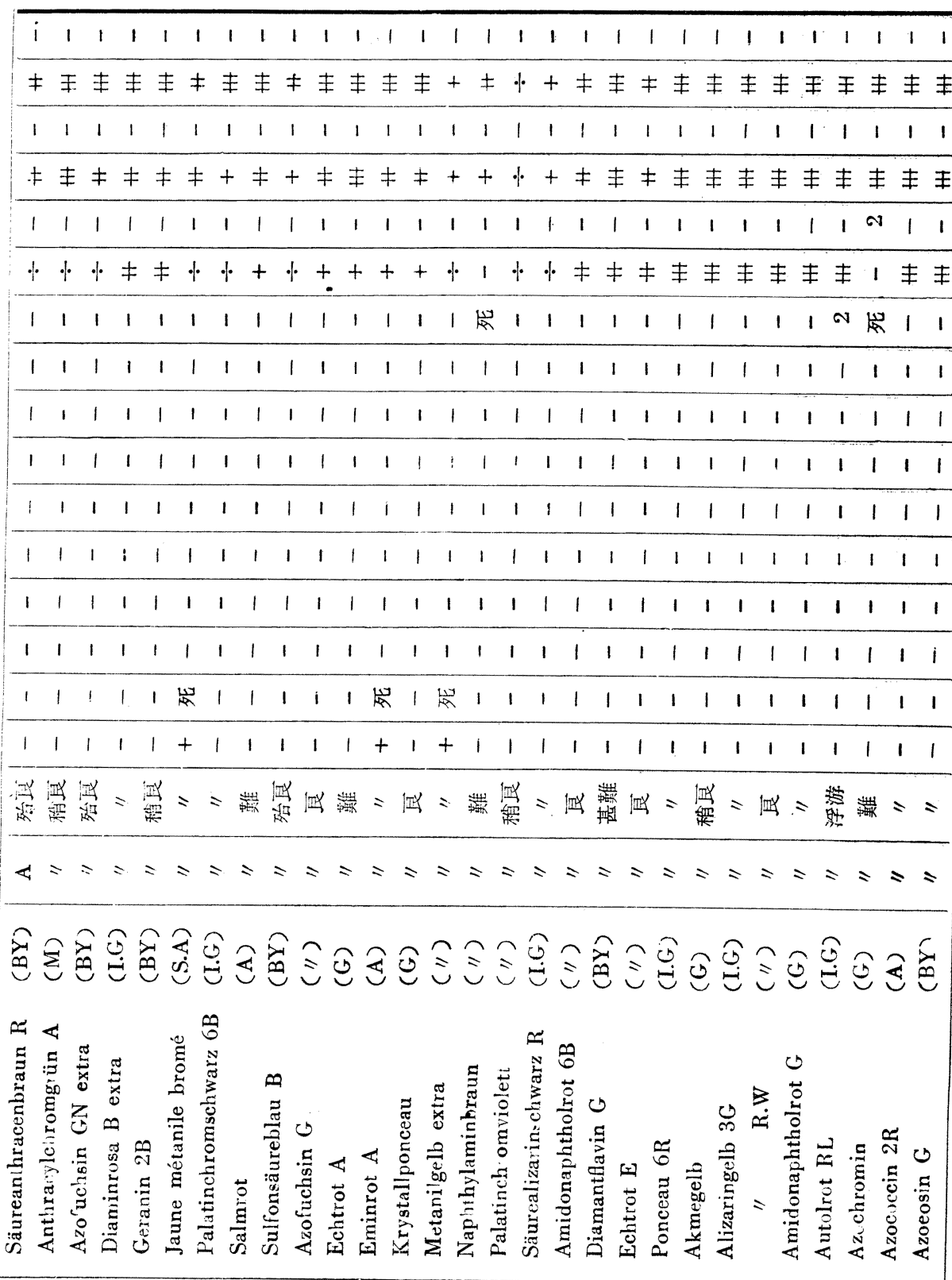

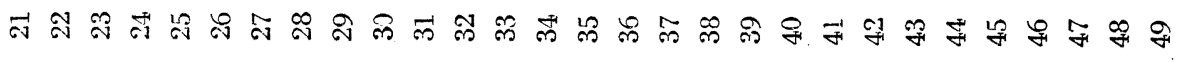




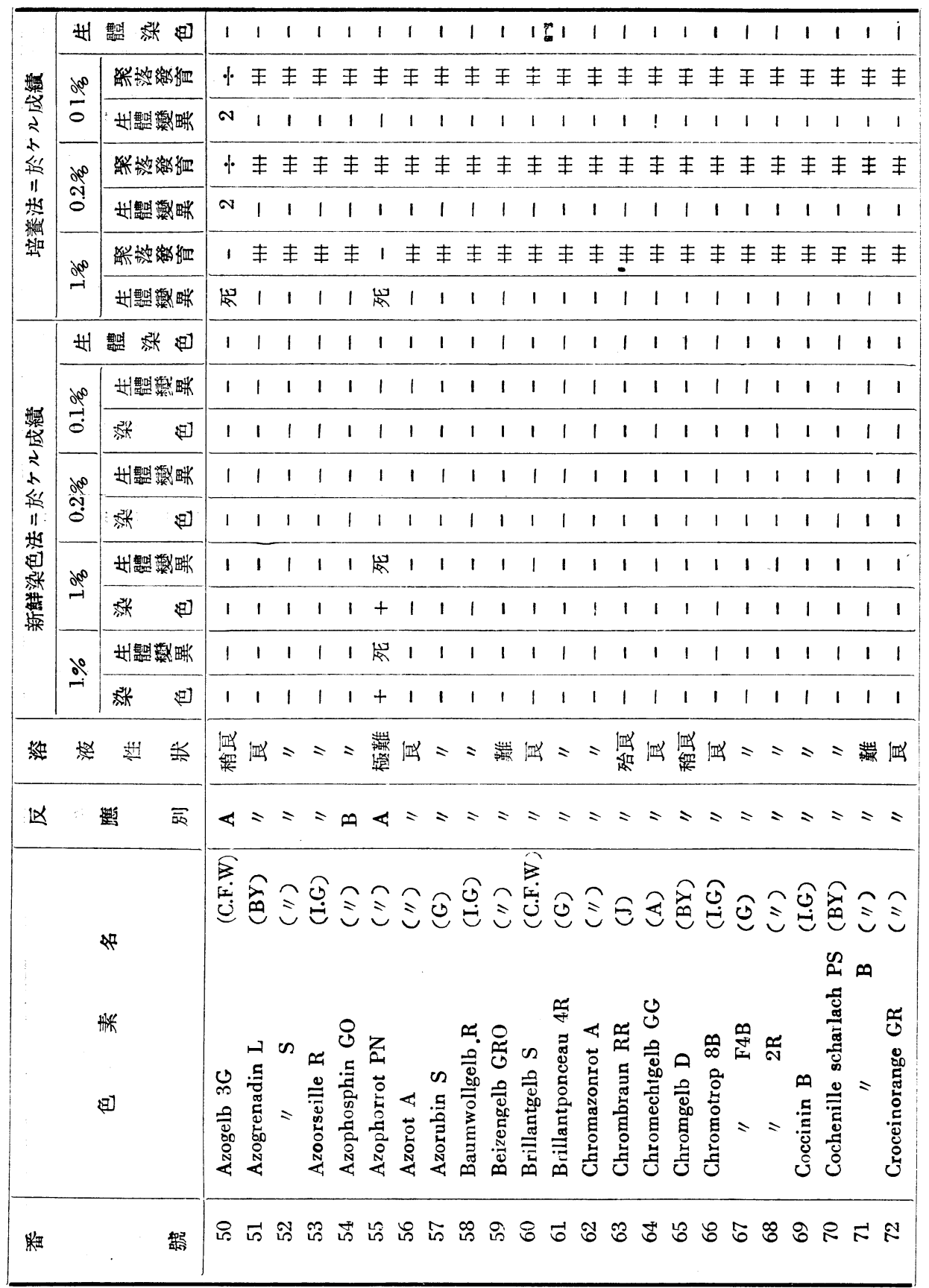




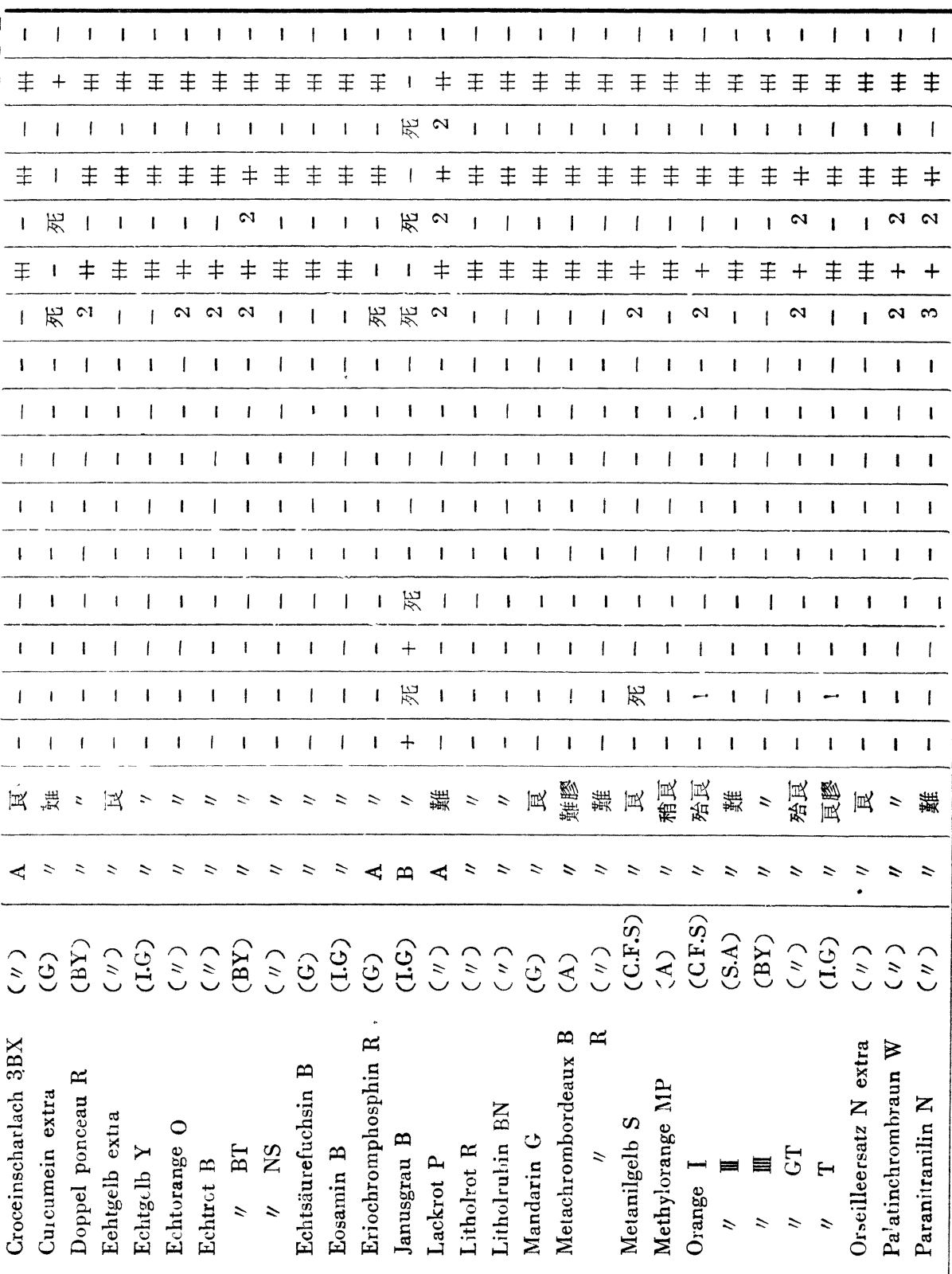

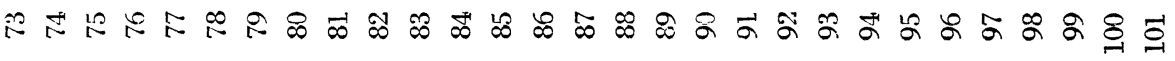




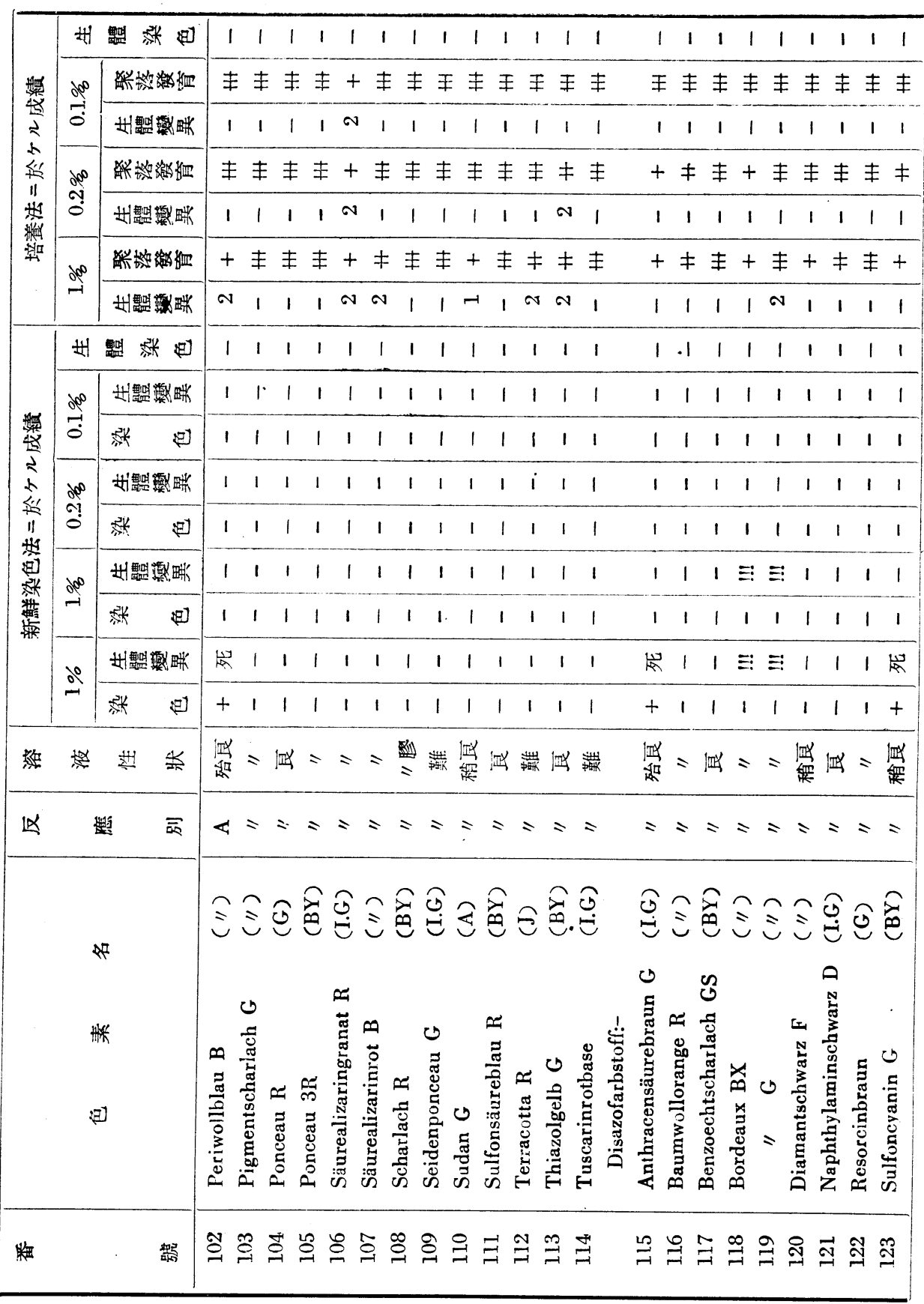


南保吉郎速

$(1247)$

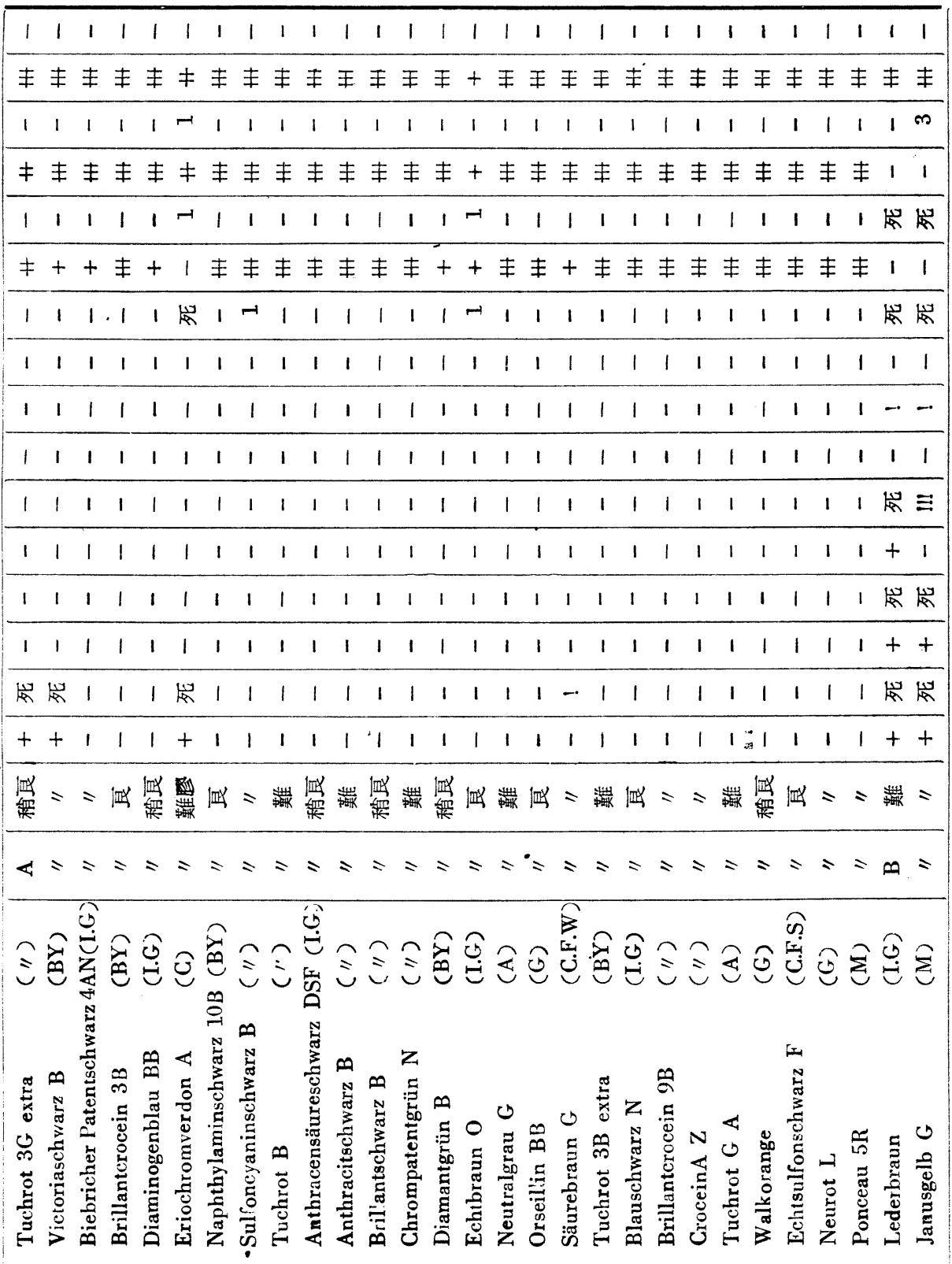

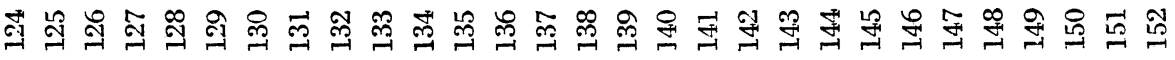




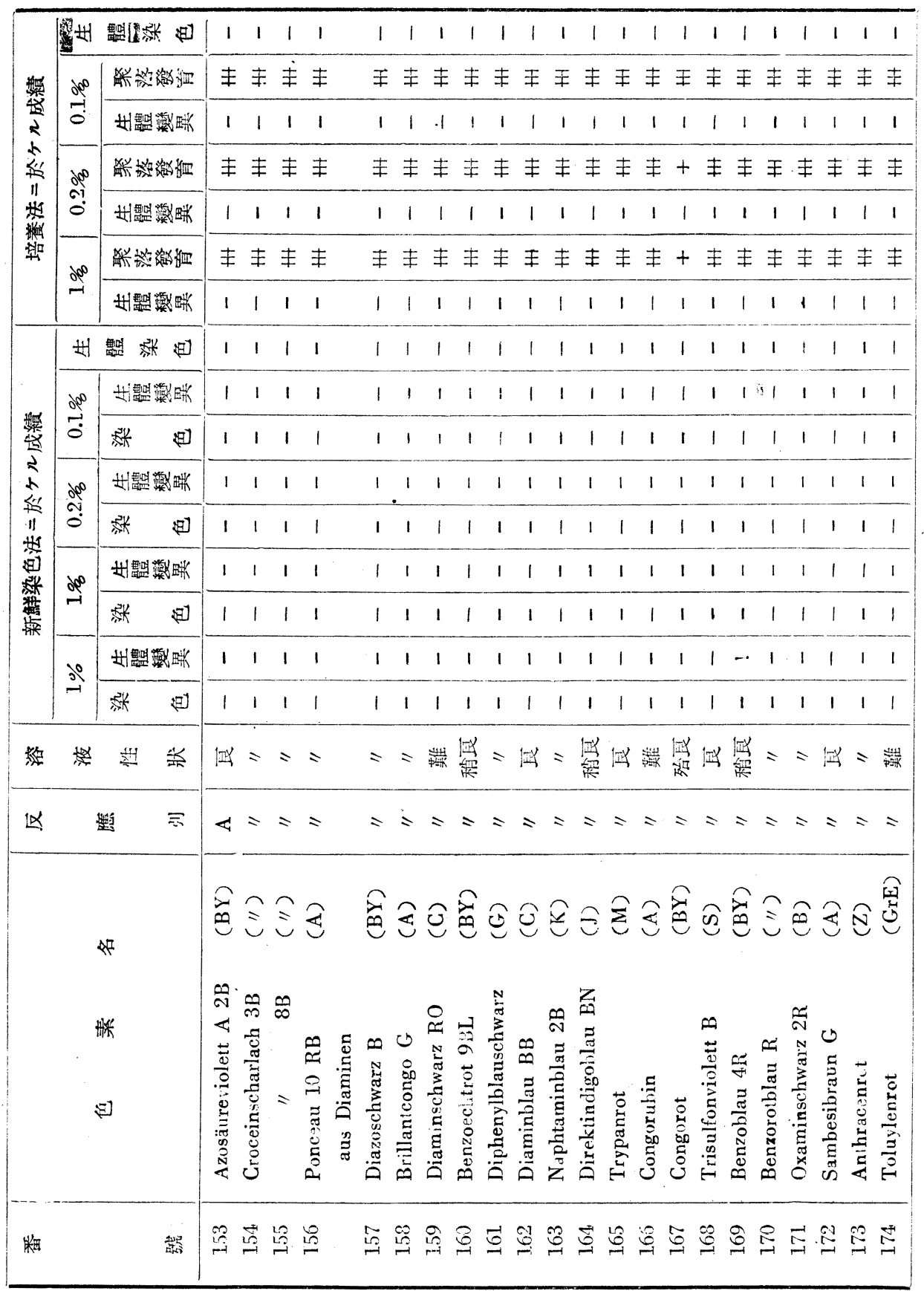




南保吉郎迅

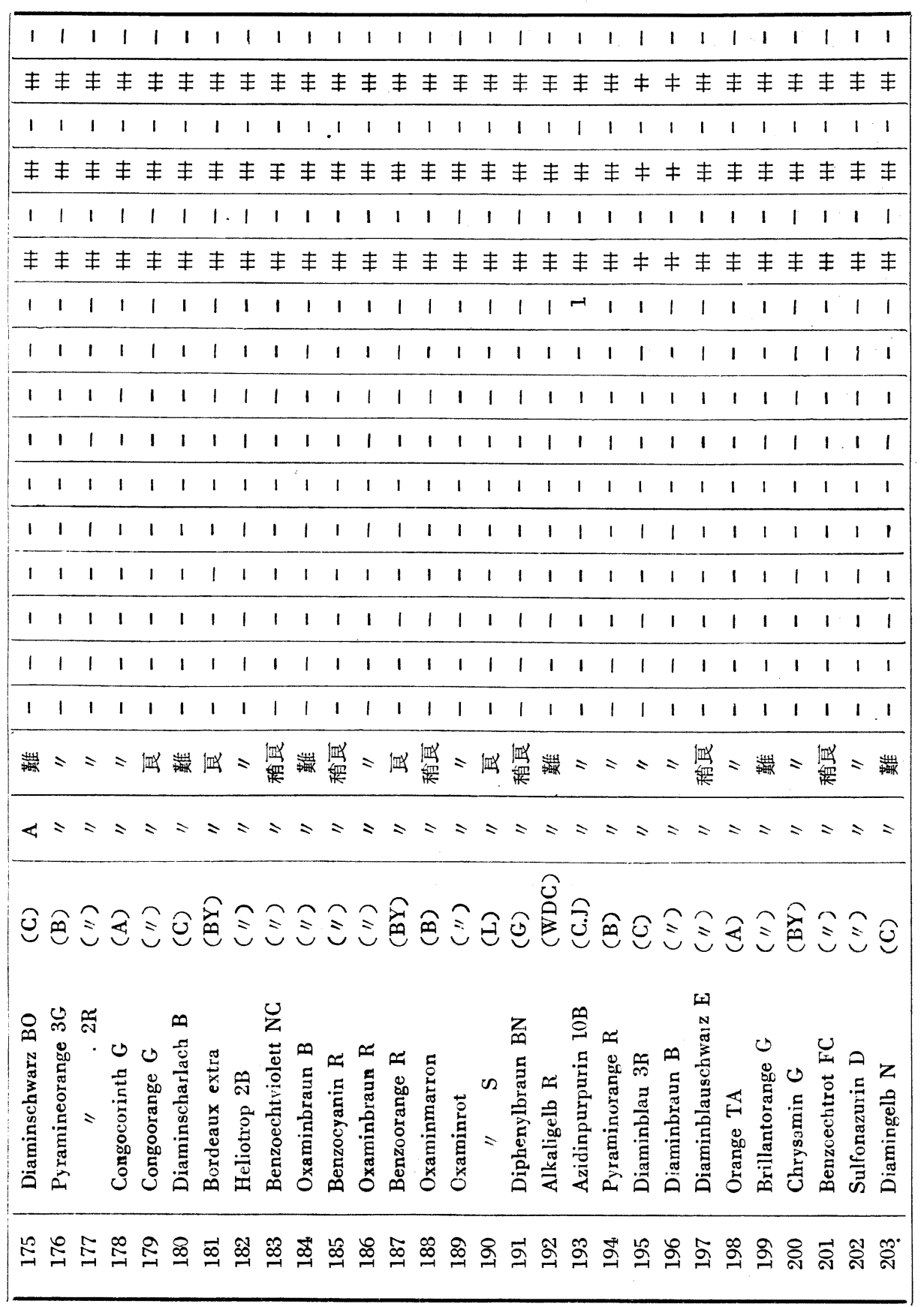




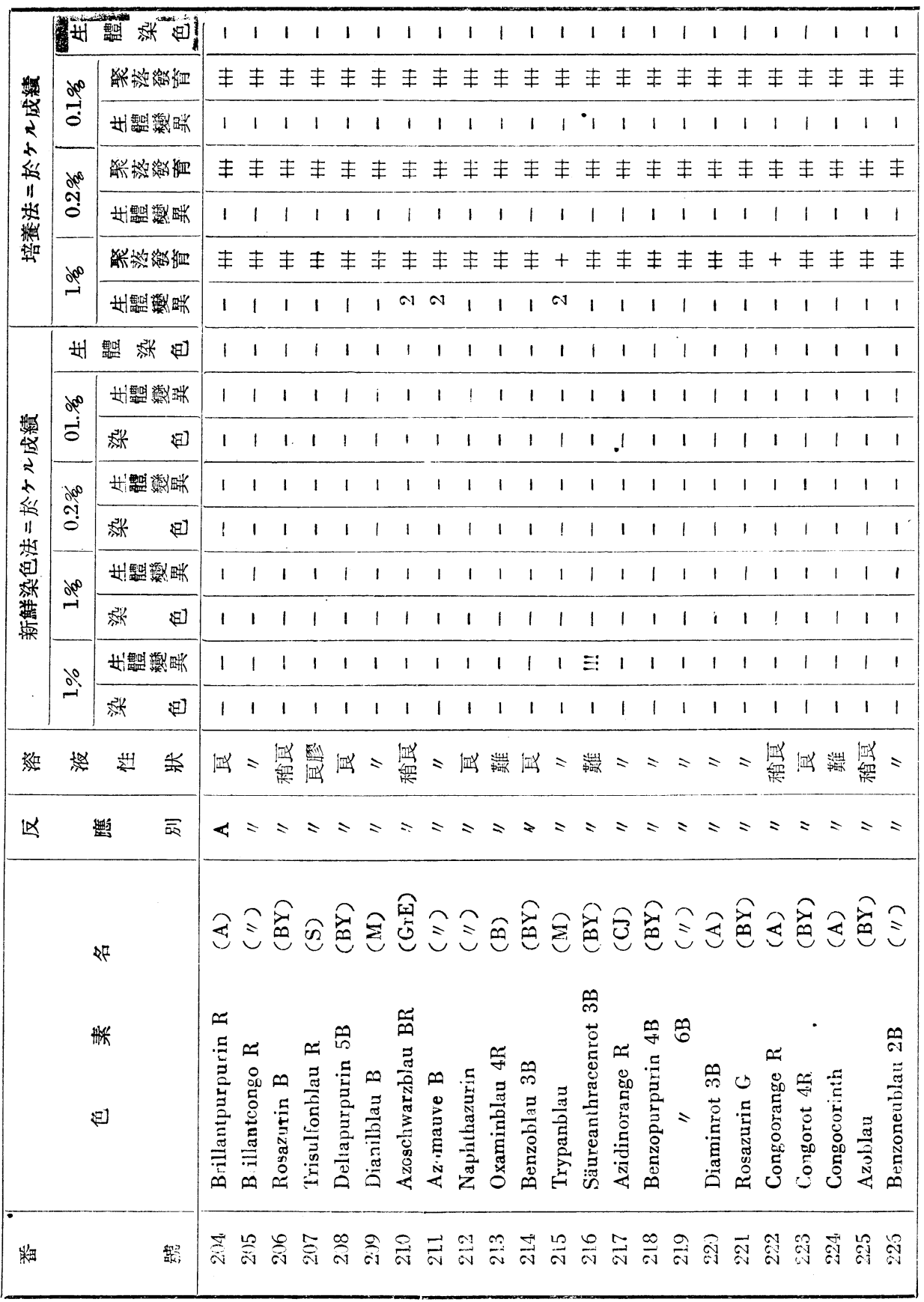




\begin{tabular}{|c|c|c|c|c|c|c|c|c|c|c|c|c|c|c|c|c|c|c|c|c|c|c|c|c|c|c|c|c|c|c|}
\hline 1 & 1 & 1 & 1 & & 1 & 1 & 1 & 1 & 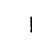 & & 1 & 1 & 1 & 1 & & $\mathrm{i}$ & & & 1 & 1 & 1 & 1 & 1 & 1 & 1 & 1 & 1 & & & 1 \\
\hline & & & & 专 & 主 & 夆 & \pm & & & & 主 & $\exists$ & & & & & & & 寿 & 7 & & 7 & 7 & & & & & & & $E+$ \\
\hline 1 & 1 & 1 & 1 & 1 & 1 & 1 & 1 & 1 & & 1 & 1. & 1 & 1 & 1 & & 1 & 1 & & 1 & 1 & 1 & 1 & 1 & 1 & 1 & 1 & 1 & & & 1 \\
\hline & & & & 寿 & 丰 & 丰 & & & & & & $\exists$ & & & & & & & & $\neq$ & & & 7 & & & & & & & $E+$ \\
\hline 1 & 1 & 1 & 1 & 1 & 1 & 1 & 1 & 1 & & 1 & 1 & 1 & 1 & 1 & 1 & 1 & 1 & 1 & 1 & 1 & 1 & 1 & 1 & 1 & 1 & 1 & 1 & & & 1 \\
\hline 王 & \pm & $\neq$ & $\neq$ & 䒠 & 寿 & 夆 & 专 & $\neq$ & $E$ & & 䒠 & 主 & 王 & 王 & & $\exists$ & & & 主 & 夆 & 专 & 夆 & 声 & \pm & 丰 & 夆 & 主 & & & $t+$ \\
\hline 1 & 1 & 1 & 1 & 1 & 1 & 1 & 1 & 1 & & 1 & 1 & 1 & 1 & 1 & 1 & 1 & 1 & 1 & 1 & 1 & 1 & 1 & 1 & 1 & 1 & 1 & 1 & & & $\Rightarrow-1$ \\
\hline 1 & 1 & 1 & 1 & 1 & 1 & 1 & I & 1 & & 1 & 1 & 1 & 1 & 1 & 1 & 1 & 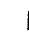 & I & 1 & 1 & $!$ & 1 & 1 & 1 & 1 & 1 & 1 & & & 1 \\
\hline 1 & 1 & 1 & 1 & 1 & 1 & 1 & I & 1 & & I & 1 & 1 & 1 & 1 & 1 & 1 & 1 & 1 & 1 & 1 & 1 & 1 & 1 & 1 & 1 & $!$ & 1 & & & 1 \\
\hline 1 & 1 & 1 & 1 & 1 & 1 & 1 & 1 & I & & 1 & 1 & 1 & 1 & 1 & 1 & 1 & 1 & 1 & 1 & 1 & 1 & 1 & 1 & 1 & 1 & 1 & 1 & & & 1 \\
\hline 1 & 1 & 1 & 1 & 1 & 1 & 1 & 1 & 1 & & 1 & 1 & 1 & 1 & 1 & 1 & 1 & 1 & 1 & 1 & 1 & 1 & 1 & 1 & 1 & 1 & 1 & 1 & & & 1 \\
\hline 1 & 1 & 1 & 1 & 1 & 1 & 1 & 1 & 1 & & 1 & 1 & 1 & 1 & 1 & 1 & 1 & 1 & 1 & 1 & 1 & 1 & 1 & 1 & 1 & 1 & 1 & I & & & 1 \\
\hline 1 & 1 & 1 & 1 & 1 & 1 & 1 & I & 1 & & I & 1 & 1 & 1 & 1 & 1 & I & 1 & I & 1 & 1 & 1 & 1 & 1 & 1 & 1 & 1 & 1 & & & 1 \\
\hline 1 & 1 & 1 & 1 & 1 & 1 & 1 & 1 & I & & 1 & 1 & 1 & 1 & 1 & I & 1 & & 1 & 1 & 1 & 1 & 1 & 1 & 1 & 1 & 1 & 1 & & & 1 \\
\hline 1 & 1 & 1 & 1 & 1 & 1 & 1 & 1 & 1 & & 1 & 1 & 1 & 1 & 1 & I & 1 & & 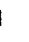 & 1 & 1 & 1 & 1 & 1 & 1 & 1 & 1 & 1 & & & 1 \\
\hline 1 & 1 & 1 & 1 & 1 & 1 & 1 & 1 & 1 & & I & 1 & 1 & 1 & 1 & I & 1 & & 1 & 1 & 1 & 1 & 1 & 1 & 1 & 1 & 1 & 1 & & & 1 \\
\hline & $=$ & & 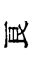 & $=$ & $s$ & $\begin{array}{l}\text { 塯 } \\
\text { 䍀 }\end{array}$ & I $\mathbb{\Psi}$ & $=$ & & $=$ & 沿 & 四 & $\leqslant$ & $\approx$ & & & & & $\leqslant$ & $\approx$ & $=$ & $\Sigma$ & 17 & $\leqslant$ & 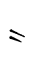 & $\Sigma$ & & & & 嚁 $\mid \mathbb{4}$ \\
\hline 4 & $\vdots$ & $=$ & 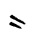 & $=$ & $=$ & $=$ & 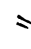 & $\approx$ & & $=$ & $=$ & $=$ & $=$ & $\approx$ & & $=$ & & $=$ & $\approx$ & $=$ & $\approx$ & $=$ & $=$ & $=$ & $\Sigma$ & $=$ & $=$ & & & $=$ \\
\hline & & & & & & & & & & & 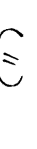 & $=$ & 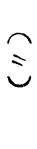 & 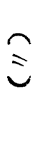 & & & & & & & 3 & 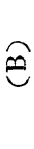 & 4 & $\infty$ & $\overline{0}$ & 5 & , & & & 2 \\
\hline 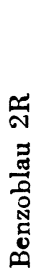 & 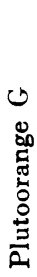 & 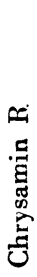 & 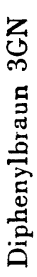 & 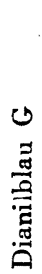 & 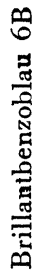 & 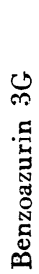 & 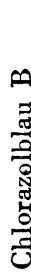 & 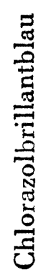 & 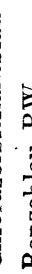 & 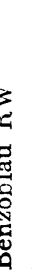 & 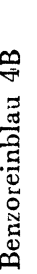 & $\begin{array}{l}\text { : } \\
\text { : } \\
=\end{array}$ & 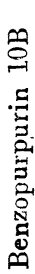 & 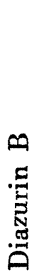 & & 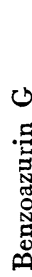 & & & 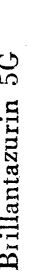 & 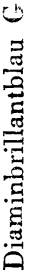 & 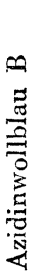 & 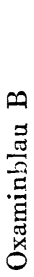 & 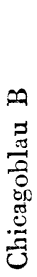 & 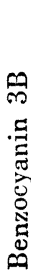 & 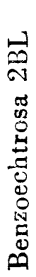 & 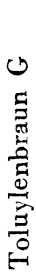 & $\begin{array}{l}0 \\
0 \\
0 \\
0 \\
0 \\
\frac{0}{0} \\
\frac{3}{3} \\
0\end{array}$ & & & 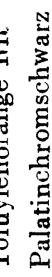 \\
\hline
\end{tabular}

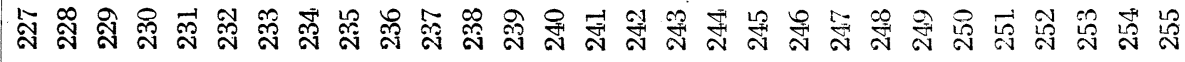




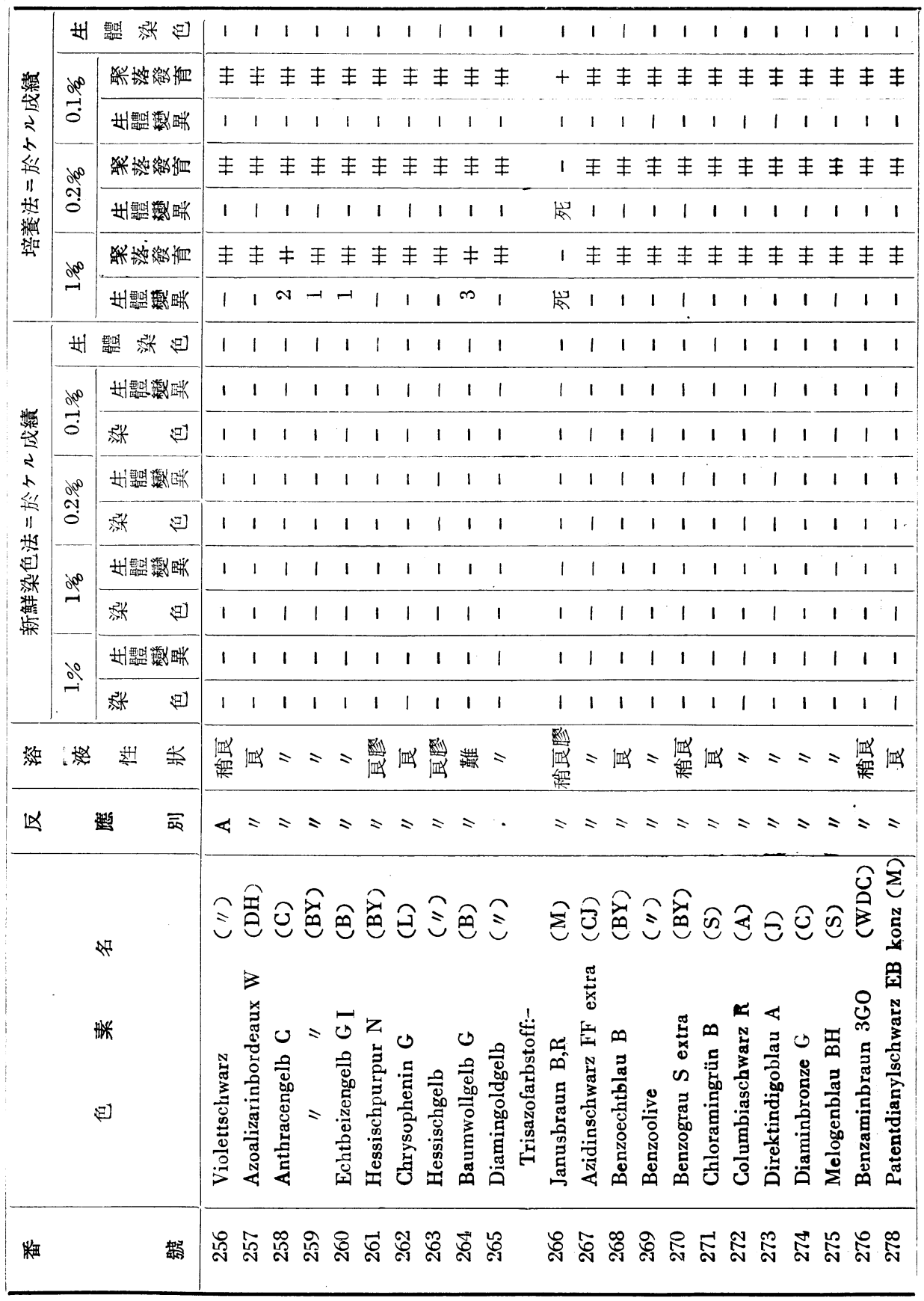




\begin{tabular}{|c|c|c|c|c|c|c|c|c|c|c|c|c|c|c|c|c|c|c|c|c|c|}
\hline 1 & 1 & 1 & 1 & 1 & 1 & 1 & 1 & 1 & 1 & 1 & 1 & 1 & 1 & I & 1 & 11 & 1 & 11 & 1 & 11 & 1 \\
\hline & $\neq$ & & F十 & $\neq \neq$ & 主 & & & & $\neq$ & 寿 & 寿 & 立 & 寿 & $\neq$ & 丰 & \#+ & + & 寿主 & $=+$ & $+\cdot \neq$ & + \\
\hline 1 & 1 & 1 & 11 & 11 & 1 & 1 & 1 & 1 & 1 & 1 & 1 & 1 & 1 & 1 & 1 & 10 & N & 11 & $\boldsymbol{N}$ & N I & 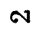 \\
\hline & F & + & 丰十 & ++ & 寿 & 末 & 丰 & ま & 丰 & F. & 末 & 末 & $\neq$ & 丰 & $\mp 引$ & F+ & + & 王 & 1 & $+\neq$ & + \\
\hline 1 & 1 & 1 & 11 & 1 & $N$ & 1 & 1 & 1 & 1 & 1 & 1 & 1 & 1 & 1 & 1 & 10 & os & 11 & 崖 & $\infty$ & $N$ \\
\hline 寿 & 寿 & + & F+ & + & $\neq$ & \#三 & 立 & 立 & 末 & 王 & ま & $\neq$ & + & 末 & $+\equiv$ & 寿+ & + & 主 & 1 & $+\neq$ & + \\
\hline 1 & 1 & 1 & 11 & 1 & $n$ & 1 & 1 & 1 & 1 & 1 & 1 & 1 & $N$ & 1 & or & $1 . m$ & $m$ & 11 & $\mu$ & $\infty 1$ & $N$ \\
\hline 1 & 1 & 1 & 11 & 1 & 1 & 1 & 1 & 1 & 1 & 1 & 1 & 1 & 1 & 1 & 1 & 11 & 1 & 11 & 1 & 11 & 1 \\
\hline 1 & 1 & 1 & 11 & 1 & 1 & 1 & 1 & 1 & 1 & 1 & 1 & 1 & 1 & 1 & 1 & 11 & 1 & 1 & 1 & 11 & 1 \\
\hline 1 & 1 & 1 & 11 & 1 & 1 & 1 & 1 & 1 & 1 & 1 & 1 & 1 & 1 & 1 & 1 & 1 & 1 & 11 & 1 & 11 & 1 \\
\hline 1 & 1 & 1 & 11 & 1 & 1 & 1 & 1 & 1 & 1 & 1 & 1 & 1 & 1 & 1 & 1 & 11 & 1 & 11 & 1 & 11 & 1 \\
\hline 1 & 1 & 1 & 11 & 1 & 1 & 11 & 1 & 1 & 1 & 1 & 1 & 1 & 1 & 1 & 1 & 11 & 1 & 11 & 1 & 11 & 1 \\
\hline 1 & 1 & 1 & 11 & 1 & 1 & 1 & 1 & 1 & 1 & 1 & 1 & ! & 1 & 1 & 1 & 11 & 1 & 1 & 1 & 11 & 1 \\
\hline 1 & 1 & 1 & 11 & 1 & 1 & 11 & 1 & 1 & 1 & 1 & 1 & 1 & 1 & 1 & 1 & 11 & 1 & 11 & 1 & 1.1 & 1 \\
\hline 1 & 1 & 1 & 11 & 1 & 1 & 11 & 1 & 1 & 1 & 1 & 1 & 1 & 1 & 1 & 11 & 1 & 1 & 11 & 1 & 11 & 1 \\
\hline & 1 & 1 & 11 & 1 & 1 & 11 & 1 & 1 & 1 & 1 & 1 & 1 & 1 & 1 & 1 & 11 & 1 & 1 & 1 & 11 & 1 \\
\hline & & $=$ & $==$ & $\begin{array}{l}\text { 盛 } \\
\text { 淁 }\end{array}$ & & 䀦 = & $=$ & $=$ & & $=$ & $=$ & $=$ & $=$ & $=$ & $=$ & $==$ & $=$ & $=s$ & $=$ & $=$ & \\
\hline & $=$ & $=$ & $=\$$ & $=$ & $=$ & $=z$ & $=5$ & $=$ & $=$ & 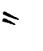 & $=$ & $=$ & $=$ & 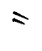 & $=$ & $==$ & $=$ & $s=$ & $=$ & $=\leqslant$ & \\
\hline & 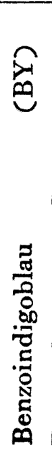 & & 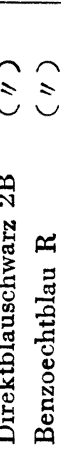 & 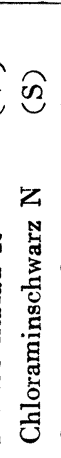 & $\widehat{\vartheta}$ & 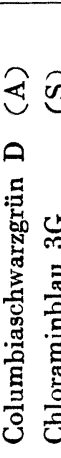 & 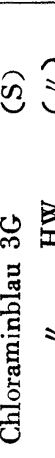 & $=$ & 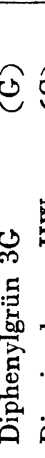 & & 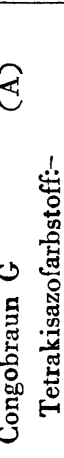 & 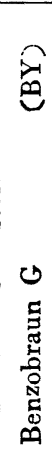 & & & 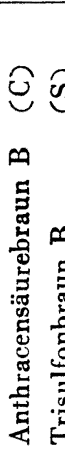 & 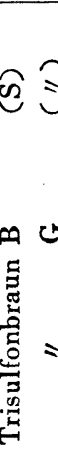 & 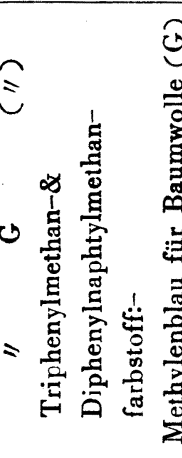 & 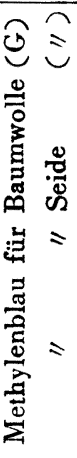 & 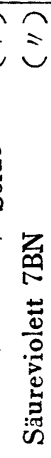 & 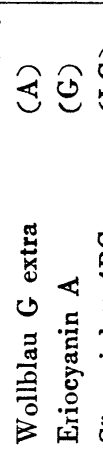 & 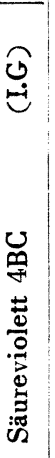 \\
\hline
\end{tabular}




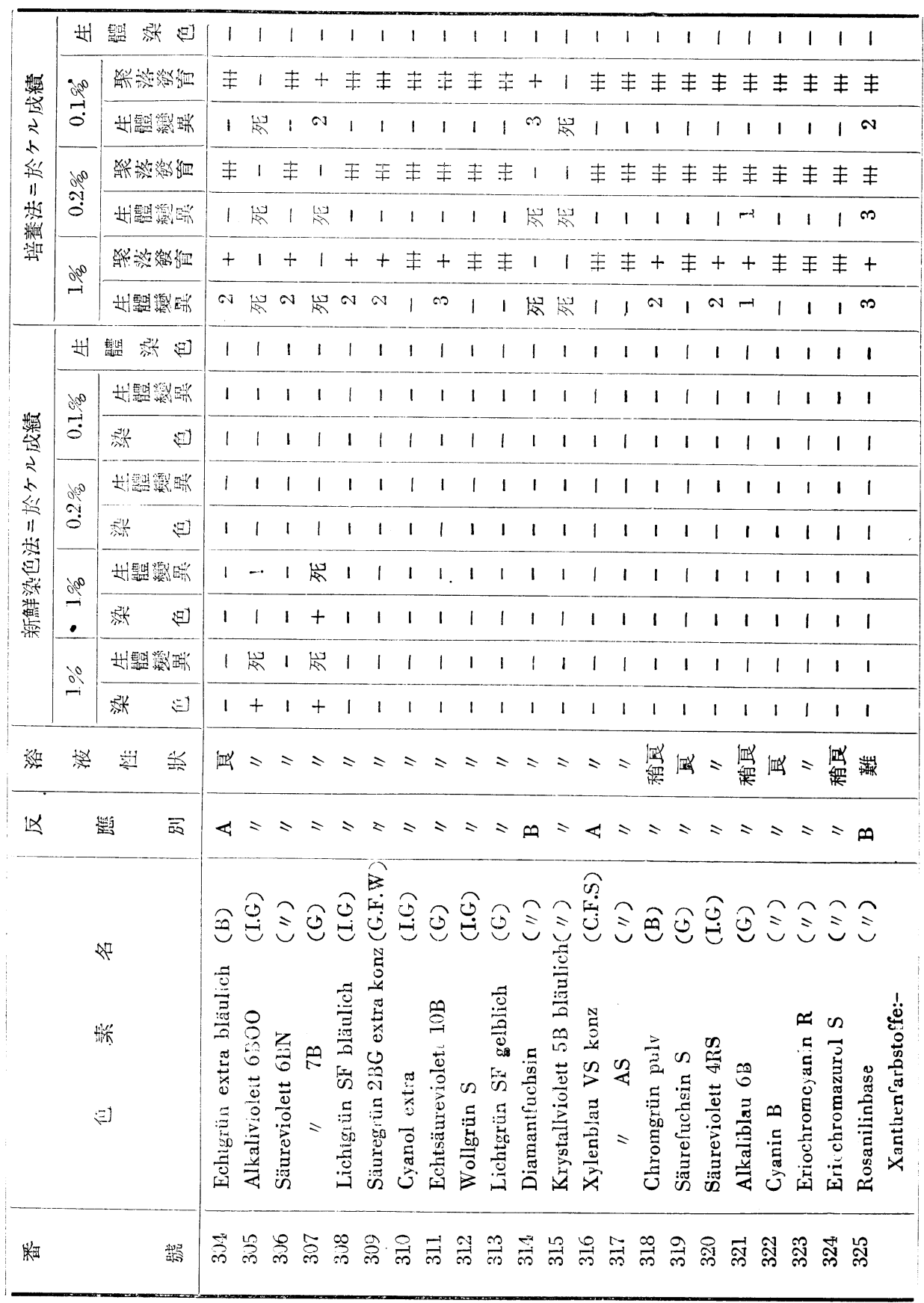


南保吉郎迅

(1255)

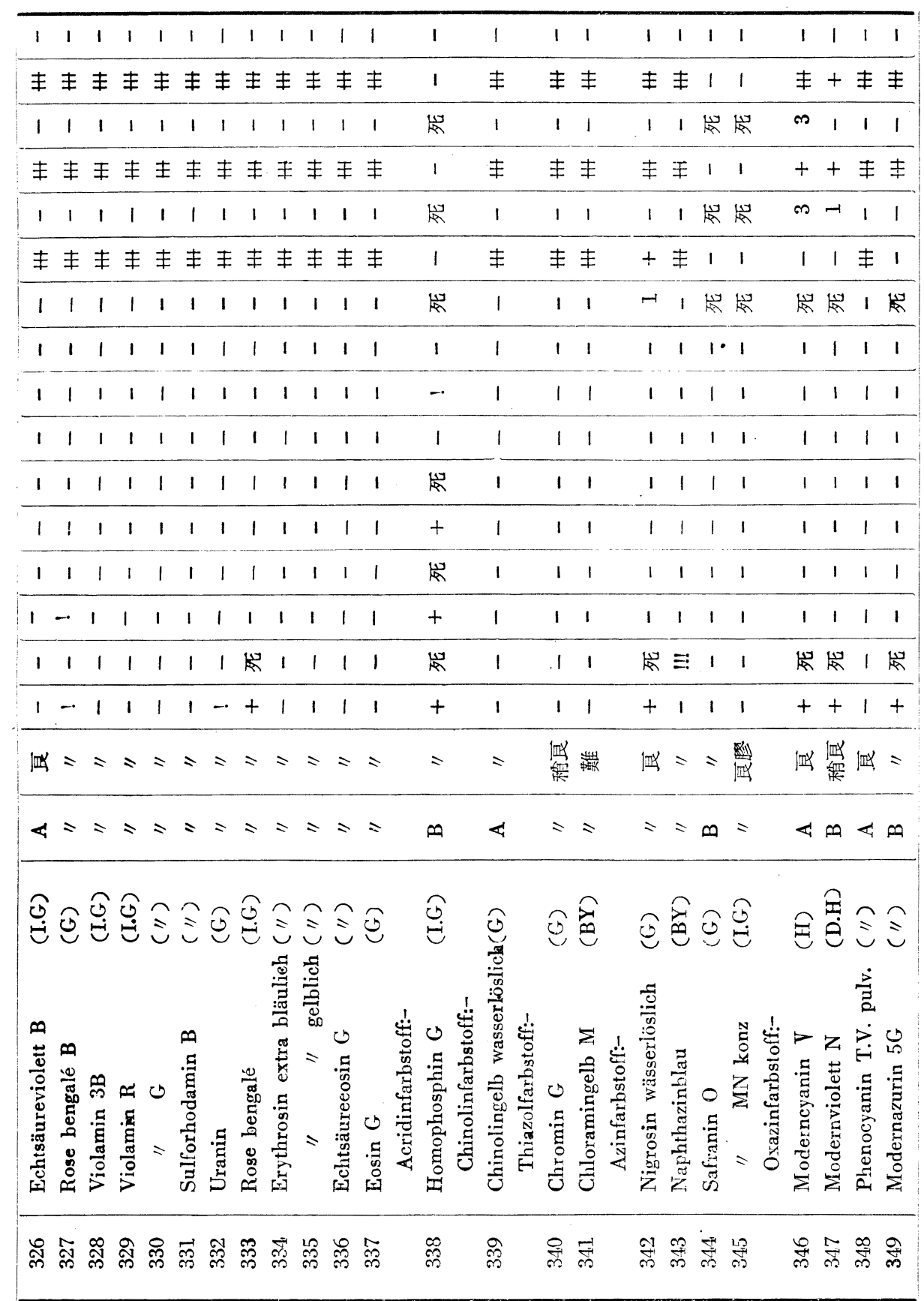




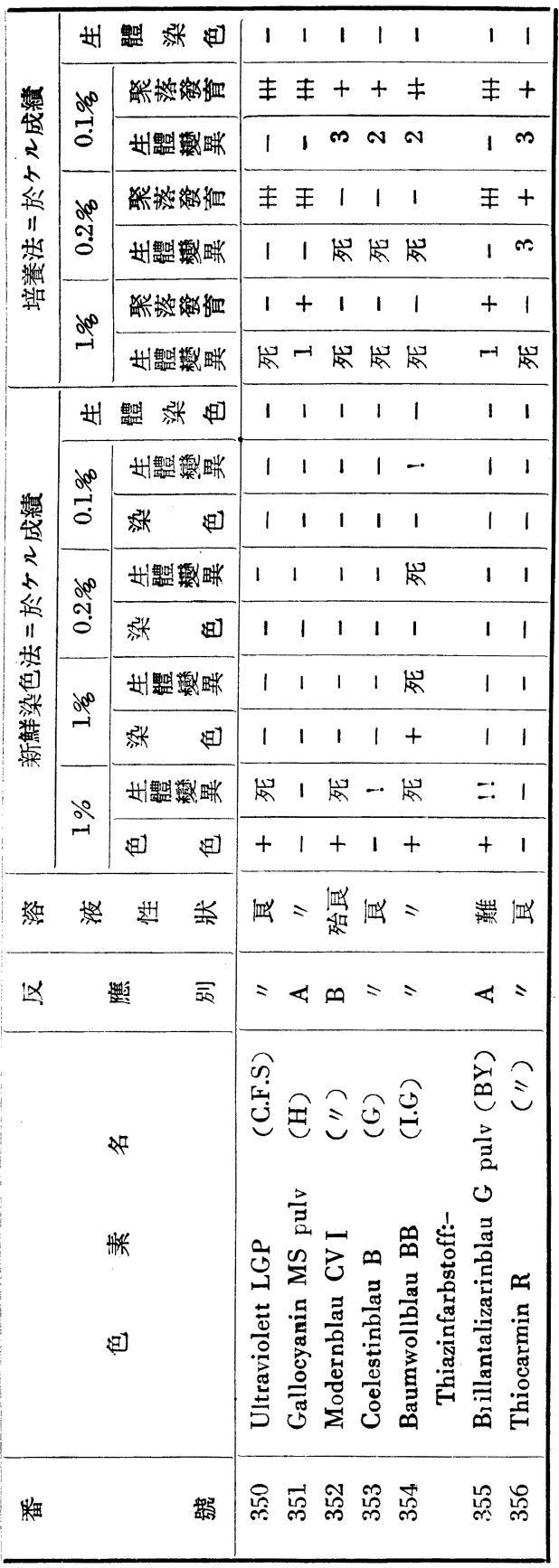

スル事前法二準ジタリ・本法二於テハ撥 育七ル原蟲ノ色素攝取ノ有無 7 檢スルト 共二生體ノ變異, 培養基上:於ヶル聚落 ノ狀况，培食基自體ノ被ムル事アルベキ 變化（脫色, 變色, 溶解) 7 觀蕃セリ。

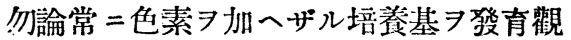
察ノ對照二備フルト共二移植ノ用 $=$ 䍀シ， 別 = 對!!得用色素加培食基习倷置セリ。

第 2 竟 實 驗成 績

望驗成績 7 一括表示ス附表第 1 ，第 2 表参!孯.

備考 1) 新鮮染色法/表中 $(+)(-)$ ，訅號八染色,晹性，陰性 テ示シ!!!!!! 死八色素ニヨリ被リタ几變化ヨ示シ! 八

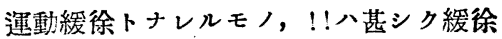
トナレルモノ，!!!生體/變形习伴フモ ノョ示ス.

2) 聚落發育欄中 $(H)(H)(+)(\div)$

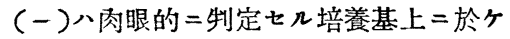
几聚落發育ノ狀熊 八發育昕盛ニシテ密生セ几聚落/存在 $\boldsymbol{~}$ 示シ, (井)八聚落發育良好ナ几モ稳粗ナ $n モ ノ,(十) 八$ 装落發育極

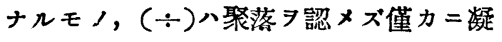
固水中 =殘存スルワ思ハシム几モノ =シ テ，(一)ハッ/何處二モ生體习認メ得ザ

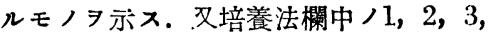
記號八(1)八運動緩徐ナ几事，(2)八䖪 體ノ矮小ニシテ鞭毛短繀肥厚シ原形質 满濁明ナルモノ，(3)八䖪體球形卜ナリ 且矮小ニシテ鞭毛モ亦短縮肥厚七几モ， ニシテ原形質ノ满濁セ几八勿踚ナリ。

3）溶液性狀ハまトシテ色素/生理的

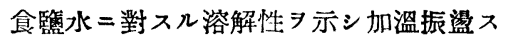

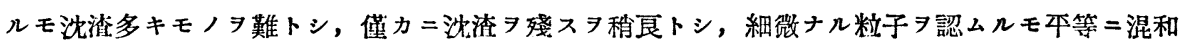

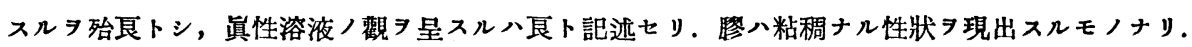




南 保 吉 郎 进

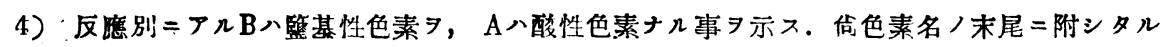
社名略號八凡テ清野, 杉山, 天野共著ノ歐交生體染色二依レリ.

\section{第 3 章 總括並 $=$ 考按}

生體染色晹性色素群八第 1 表ニ示スガ如ク54種 7 算シ, 第 2 表八生體染色除性色素群 括表示セルモノナリ．而シテ之等供試色素群ノ理學的性狀並二親和力, 各種可檢體ノ成績卜 ノ比較, 色素ノ生體=及ボス機能的, 形態的變異, 色素加培養基上ノ發育狀態二關シテハ編 ア新タンシテ記述スペシ.

惟フニ本實驗ニ於テ八生䯠染色陽性ノ制定入既述ノ如ク專ラ生體ノ運動

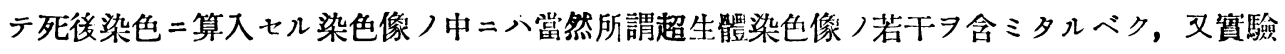
操作上ヨリ見レバ寧口原義ノ超生體染色トモ稱シ得ベキナレバ生體染色陽性卜認メタル染色 像ノ中ニモ理論的ニ八超生體染色像卜見ルベキ染色像ノ存シタルハ言 $习$ 俟タザルベシ。

而シテ從來生活機能ノ觀察困難ナル組織細胞=於テ生骼, 超生體, 死㣦染色ノ 3 者二分ツ 事ノ容易ナシザル事ヨリ之等 3 者八連續セル一楾上ニアリト七ラレ, 肥㭌顆粒細胞/超生體

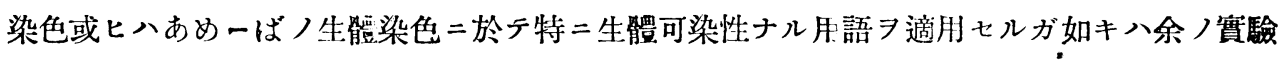
=於テモソノ染色像ノ觀察制定: 當リ屢首肯セル所ナリ・サレト本可檢生體八生活機能)變

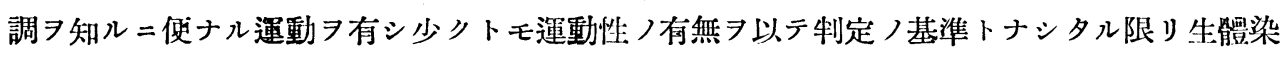

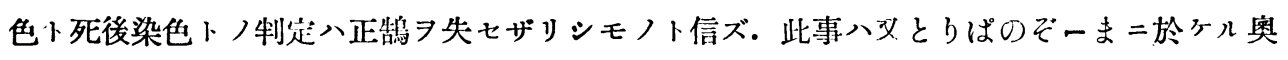
川氏ノ貫驗成績二於テモ特二附言セラレタル所ナリ．而シテ蓮動ノ變調二關シテハ內藤氏ガ あめーばノ實驗二於テ述へタルガ如媣色像ノ發現=先ダチテ生體ノ形態異常习發現シタル

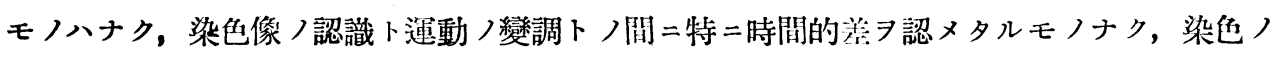

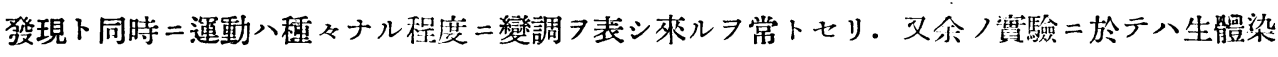
色陽性像八凡テ新鮮染色法ヨ以チ確認サレタルモノニシテ, 培養法二於テハ唯 3 程ノ色素二 ノミ稍注目スベキ所見、ヨ得タルニ過ザリシ事, 生體染色陽性群ノ凡テガ笽基性色素ナリシ事 等八從來ノ成績二比シテ聊カ異ナル所ナルモ, 彼我ノ化試色素ノ一致キザルノミナラズ, 䨢 驗操作上ノ要約 $=$ 相等シカラザルモノアル＝起因七ルモノト思惟ス。

\section{結論}

1） N-N_N培養基ヨ基本ト七ル一固形培養基)科面上:純粹培養七ルれーしゆまにあ・ど

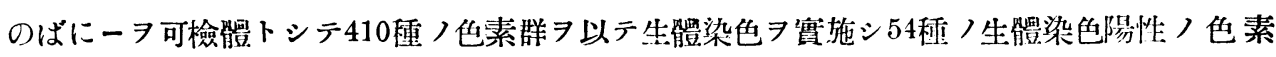
群ヨ得タリ。 
2）上記ノ生體染色陽性色素群八凡テ新鮮染色法ニ依リ確認サレタルモノニシテ培餋法ニ 於テハシヨ求メ得ザリキ.

3）該色素群八凡テ鹽基性色素二屬ス.

終二臨ミ御懇篤ナル御指導ト御校閲ノ勞

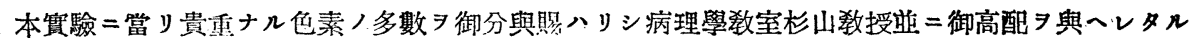

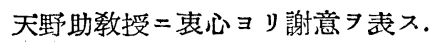
（文献後出） 